\title{
Gastroprotective and Antioxidant Effect of Gloriosa Superba on Indomethacin-Induced Gastric Ulcers in Rats
}

\section{Authors \\ Siddhi Ashokkumar Mehta Falguni*, Mrs. Rachana D. Sarawade**, Vishakha Trivedi, Ayyub Shaikh}

*Department of Pharmacology, Dr. L.H.Hiranandani College of Pharmacy, Ulhasnagar, Mumbai

**Assistant Professor and HOD Pharmacology, Dr.L.H.Hiranandani College of Pharmacy, Ulhasnagar,

Mumbai

Corresponding Author

\section{Siddhi Ashokkumar Mehta Falguni}

Department of Pharmacology, Dr. L.H.Hiranandani College of Pharmacy, Ulhasnagar, Mumbai

Email: siddhiamehta@gmail.com

\begin{abstract}
Gloriosa superba plant is well documented traditionally in Ayurvedic system of medicine and is used in treating many diseases. The present study was undertaken to evaluate the gastroprotective effect of Gloriosa superba tuber extract (GSTE) on rats at the dose of $110 \mathrm{mg} / \mathrm{kg}$ body weight. Administration of test drug $(110 \mathrm{mg} / \mathrm{kg})$ reduced gastric lesions as compared to Indomethacin $(25 \mathrm{mg} / \mathrm{kg})$ treated group. In vivo antioxidant levels were also evaluated. It was observed that administration of Indomethacin caused significant decrease in levels of SOD, GSH, GSHPX and increase in level of LPO. But reverse trend was seen in rats pre-treated with test drug, that is increase in levels of SOD, GSH, GSHPX and decrease in level of LPO. The results suggest that the gastroprotective activity of methanolic extract of Gloriosa superba tuber can be contributed to its constituents and antioxidant potential.
\end{abstract}

Keywords: Gloriosa superba, gastroprotective, antioxidant, antioxidant enzymes.

\section{INTRODUCTION}

Gastric ulcer is a common disease affecting many people worldwide. Some factors that are identified in the etiology of this disorder include stress, cigarette smoking, alcohol consumption, nutritional deficiencies and infections. However, the over-ingestion of non-steroidal antiinflammatory drugs (NSAIDs) and $\mathrm{H}$ pylori infection remains the predominant cause of peptic ulcer disease. The gastric ulcer disease was observed to correlate with changes in several physiological parameters, such as Reactive oxygen species (ROS), NO, lipid peroxidation and gastric acid over secretion. Treatment of gastric ulcer is considered a clinical problem due to the increasingly widespread use of NSAIDs and lowdose aspirin. Despite the effectiveness of reciprocal antiulcer drugs such as the antacids, anticholinergics, proton pump inhibitors and histamine $\mathrm{H}-2$ receptor antagonists, the majority of them possess adverse effects that limit their usage. Nowadays, the pursuit to discover alternative therapies to treat gastric ulcer is of high concern. A large number of natural antiulcer 
compounds have been isolated from medicinal plants and the common chemical classes of bioactive compounds that have been identified as possessing antiulcer activity are the tannins Flavonoids, Saponins, Mucilages among others ${ }^{1}$.

Gloriosa superba is perennial creeper, herbaceous, stout, climbing herb with wavy edged yellow and red flower belonging to family liliacea. Many activities have been reported such as Anti inflammatory, antioxidant, analgesics, antihelmentic, hepatoprotection, anti implantation and anti anxiety etc.

The plant is well documented traditionally in Ayurvedic system of medicine and is used in inflammations, gout, rheumatoid arthritis, and gonorrhoea and relieving fever. Extracts of the tuber are reported to cure ulcer, leprosy, bleeding piles, skin diseases and also have anti-dote property for snake bite. It is classified in Ayurvedic system as Garbhapatani (abotifacient) and used for promoting labour pains. The leaf infusion is extensively used to overcome jaundice, parasitic helminthes infections and killing lice in hair ${ }^{2}$.

\section{MATERIALS AND METHODS}

\subsection{Plant material}

Tubers of Gloriosa superba was collected from Bharat trading centre, Mumbai. Authentification of these tubers was done from Khalsa College of arts, commerce and science, Mumbai. (Specimen number sm301013).

\subsection{Extraction of Gloriosa superba}

The dried tuber was grind in mixer grinder to get course powder. This coarse powder was used for methanolic extraction. The plant extract were prepared by soxhlet apparatus. 100 gm of coarse powder were repeatedly extracted with methanol in a $500 \mathrm{ml}$ R.B.F. with $250 \mathrm{ml}$ solvent. The reflux time for each solvent was 25 cycle for complete extraction. The extract was filtered through Whatman filter paper. The filtrate was collected and concentrated by using rotary evaporator under controlled condition of temperature and pressure. The extract was concentrated to dryness to yield crude residue. The concentrated extract was stored in small vials for further use ${ }^{3}$.

\subsection{Phytochemical screening}

Identification of the chemical constituents was carried out on the plant extract in order to determine the presence of various phytochemical constituents using specific reagent ${ }^{4,5}$.

\subsection{Animals}

A total of 24 either sex, Sprague dawley rats, weighing 180-200 gm have been used for experiment. The animals were procured from Bharat serum Ltd, Thane. These animals were acclimatized in animal house of Dr.L.H.Hiranandani college of pharmacy (Registration No- 879/ac/05/CPCSEA) under standard husbandry condition i.e. room temperature of $24 \pm 10 \mathrm{C}$; relative humidity 45 $55 \%$ and 12:12 hr light dark cycle. The experiments were conducted according to the ethical norms approved by the Institutional animal Ethical committee (IAEC).

\subsection{Acute toxicity studies of Gloriosa superba}

In order to determine the acute toxicity of Gloriosa superba, the animals were divided into two groups, of six rats each. Animals were provided with single oral dose of $2000 \mathrm{mg} / \mathrm{kg}$ of test drug and control group provided with vehicle i.e. saline solution. Animals were observed individually after dosing atleast once during the first $30 \mathrm{~min}$, periodically during the first $24 \mathrm{hr}$, with special attention given during first $4 \mathrm{hr}$ and daily thereafter for a total of 14 says. The parameters observed were diarrhoea, vomiting, salivation, urination, tremor, lethargy, gait, locomotion, adverse behaviour, hypersensitivity ${ }^{6}$.

\subsection{Indomethacin induced gastric damage}

In this experiment, effects of Gloriosa superba and Ranitidine on the Indomethacin-induced gastric damage were determined. The protective effect of Gloriosa superba was compared with the $\mathrm{H}_{2}$ receptor blocker, ranitidine. Animals were divided 
into the four groups each consisting of six rats. Animals were fasted for $24 \mathrm{hr}$ with access to drinking water up till $2 \mathrm{hr}$ before experiment. Gloriosa superba $(110 \mathrm{mg} / \mathrm{kg})$ was suspended in saline solution and ranitidine $(50 \mathrm{mg} / \mathrm{kg})$ were administered to test group and Standard group respectively. Saline solution was administered orally to Control group. Some 5 min later Test group, Standard group, Control group and Disease control group were administered with Indomethacin $(25 \mathrm{mg} / \mathrm{kg})$ orally. After $6 \mathrm{hr}$, animals were sacrificed and rat stomach was removed for further studies ${ }^{7}$.

\subsection{Determination of Ulcer index}

Ulcer index was calculated according to Main and Whittle. The ulcerative index was calculated and severity of gastric mucosal lesions which graded as follows:

Grade 1: less than $1 \mathrm{~mm}$ lesions

Grade 2: 1-2 mm lesions

Grade 3: more than $2 \mathrm{~mm}$ lesions

The ulcerative index was calculated using formula:

$\mathrm{UI}=1 \mathrm{x}$ (no of lesions of grade 1$)+2 \mathrm{x}$ (no of lesions of grade 2$)+3 x$ (no of lesions of grade 3 )

The overall score was divided by a factor 10 to get Ulcer index.

The curative ratio from ulcer index was calculate for the treated groups according to method described to by Akhtar and Ahamed using following equation,

$$
\text { Curative ratio }=\frac{\text { LUC-LUT } \times 100}{\text { LUC }}
$$

Where:

LUC -Length of ulcer in Disease control group

LUT - Length of ulcer in treated group ${ }^{8}$.

\subsection{Biochemical investigation of stomach tissue}

\subsubsection{Superoxide dismutase (SOD) activity}

SOD activity was measured according to Sun et al. The activity of the enzyme was evaluated by measuring its capacity to inhibit the photochemical reduction of nitro blue tetrazolium (NBT). In this assay, the photochemical reduction of riboflavin generates $\mathrm{O} 2-$ that reduces the NBT to produce formazan salt, which absorbs at a wavelength of $560 \mathrm{~nm}$. In the presence of SOD, the reduction of the NBT is inhibited because the enzyme converts the superoxide radical to peroxide.

Homogenates (10\% of tissue in phosphate buffer) were centrifuged (10 minutes, $3,600 \mathrm{rpm}, 4 \circ \mathrm{C}$ ), and the supernatant was removed and centrifuged a second time (20 minutes, $12,000 \mathrm{rpm}, 4 \circ \mathrm{C}$ ). The resulting supernatant was assayed. In a dark chamber, $1 \mathrm{~mL}$ of the reactant $(50 \mathrm{mM}$ phosphate buffer, 100nM EDTA, and $13 \mathrm{mMl}$ methionine, $\mathrm{pH} 7.8$ ) was mixed with $30 \mu \mathrm{L}$ of the sample, 150 $\mu \mathrm{L}$ of $75 \mu \mathrm{M}$ NBT, and $300 \mu \mathrm{L}$ of $2 \mu \mathrm{M}$ riboflavin. The tube containing the resulting solution was then read using a spectrophotometer at 560 $\mathrm{nm}$. The results are expressed as the quantity of SOD necessary to inhibit the rate of reduction of the NBT by $50 \%$ in $\mathrm{u} / \mathrm{g}$ tissue weight ${ }^{9}$.

\subsubsection{Determination of lipid peroxidation (LPO)}

The level of LPO in gastric tissue homogenate was determined by measuring the release of thiobarbituric acid reactive substance (TBARS) in terms of MDA equivalent using molar extinction coefficient as described by Okhawa et al. Briefly the reaction mixture consisted of $0.2 \mathrm{ml}$ of homogenate, $0.2 \mathrm{ml}$ of $8 \% \mathrm{SDS}, 1.5 \mathrm{ml}$ of $20 \%$ acetic acid (adjusted to $\mathrm{pH} 3.5$ with $\mathrm{NaOH}$ ), and $1.5 \mathrm{ml}$ of $0.8 \%$ aqueous solution of thiobarbituric acid (TBA). The mixture was made for a final volume of $5 \mathrm{ml}$ with distilled water and heated in a water bath for 60 mins. The reaction mixture was then added to $5 \mathrm{ml}$ mixture of $\mathrm{n}$ butanol and pyridine $(15: 1 \mathrm{v} / \mathrm{v})$. The absorbance of the organic layer was measured at $532 \mathrm{~nm}$. Results were expressed in nm MDA per mg wet tissue (nm mg tissue $\left.{ }^{-1}\right)^{10}$.

\subsubsection{Total Glutathione (GSH) determination}

This analysis was done on method described by Sedlak and Lindsay. To $0.1 \mathrm{ml}$ of homogenized tissue were added to a solution containing 5\% trichloroacetic acid and $5 \mathrm{mM}$ EDTA and centrifuged for $10 \mathrm{~min}$ at $15000 \mathrm{~g}\left(4^{\circ} \mathrm{c}\right)$. The 
supernatant was added to $0.4 \mathrm{M}$ tris-EDTA buffer ( $\mathrm{pH} 8.9$ ) and then mixed thoroughly and followed by the addition of $40 \mathrm{ul}$ of $10 \mathrm{mM} 3,3$ - dithiobis(6nitrobenzoic acid) (DTNB) in methanol. The absorbance was read at $412 \mathrm{~nm}$ after $5 \mathrm{~min}$. Results were expressed in $\mathrm{um} / \mathrm{mg}$ tissue weight ${ }^{8}$.

\subsubsection{Glutathione peroxidise (GPx) activity}

Rotruck and his coworkers measured the activity of glutathione peroxidase (Rotruck et al., 1973). The reaction mixture contained $0.2 \mathrm{ml}$ of $0.4 \mathrm{M}$ tris $\mathrm{HCl}$ buffer $(\mathrm{pH}=7.0) 0.2 \mathrm{ml}$ standard glutathione (GSH) $0.1 \mathrm{ml}$ of $0.2 \mathrm{mM} \mathrm{H}_{2} \mathrm{O}_{2}$. The contents were incubated at $37^{0 \mathrm{C}}$ for 10 minutes. The supernatant was assayed for glutathione content by using Ellman's reagent (19.8 mg of 5, 5 '-dithiobis nitrobenzoic acid (DTNB) in $100 \mathrm{ml}$ of $0.1 \%$ sodium nitrate). GPx activity was expressed as ug of GSH utilized /minute/mg tissue $^{7}$.

\subsection{Histopathological examinations}

Specimens of the gastric walls of each rat were fixed in $10 \%$ buffered formalin and processed in a paraffin tissue processing machine. Sections of the stomach were made at a thickness of $5 \mu$ and stained with Hematoxylin and eosin for histological evaluation.

\section{STATICAL ANALYSIS}

All values were reported as mean + S.E.M. Results were significantly analyzed using one way
ANOVA by Dunnett test $\mathrm{p}<0.05$ was considered to be significant.

\section{RESULT}

\subsection{Phytochemical screening}

Preliminary phytochemical analysis of the methanolic extract of Gloriosa superba revealed the presence of Tannis, Flavonoids, Steroids, Alkaloids, and Carbohydrates, Glycosides and Mucilages.

\subsection{Acute toxicity studies}

Acute toxicity studies was carried out to evaluate toxicity and to determine the minimum lethal dose of the drug extract. It was found that no mortality and changes in behaviour were observed up to dose of $550 \mathrm{mg} / \mathrm{kg}$. Therefore $1 / 5$ of the $550 \mathrm{mg} / \mathrm{kg}$ dose $(110 \mathrm{mg} / \mathrm{kg})$ was selected for gastroprotective activity.

\subsection{Gastric lesions}

Gastroprotective activity of Gloriosa superba extract in Indomethacin- induced gastric ulcers model is shown in fig. Treatment of rats with Indomethacin produced typical lesions in the gastric mucosa resulting into substantial ulcer index (\%). This was significantly reduced in pretreated rats with Ranitidine and test drug (Gloriosa superba extract) as compared to ulcer index of disease control group. \% curative ratio was seen significantly in pre-treated group.

Table-1: Effect of GSTE on Ulcer area and curative ratio.

\begin{tabular}{|l|l|l|l|l|}
\hline Treatment & Dose $(\mathrm{mg} / \mathrm{kg})$ & $\mathrm{N}$ & Ulcer index & \% curative ratio \\
\hline Control & Saline & 6 & $0 \pm 0$ & $0 \pm 0$ \\
\hline Disease control & 25 & 6 & $3.150 \pm 0.1565$ & $0 \pm 0$ \\
\hline Standard & 50 & 6 & $0.6167 \pm$ & $80.42 \pm$ \\
& & & $0.0600^{* * *}$ & $1.908^{* * *}$ \\
\hline Test & 110 & 6 & $1.083 \pm$ & $65.60 \pm$ \\
& & & $0.0600^{* * *}$ & $1.907 * * *$ \\
\hline
\end{tabular}

Animal number $(\mathrm{N})=6$, Each data suggest Mean $\pm \mathrm{SEM}$

One-way ANOVA followed by Dunnett's test is applied for statistical analysis, *** Significant at $\mathrm{p}<0.05$ when test group and standard group compared to disease control group. 
JMSCR Vol.||03||Issue||08||Page 7064-7072||August

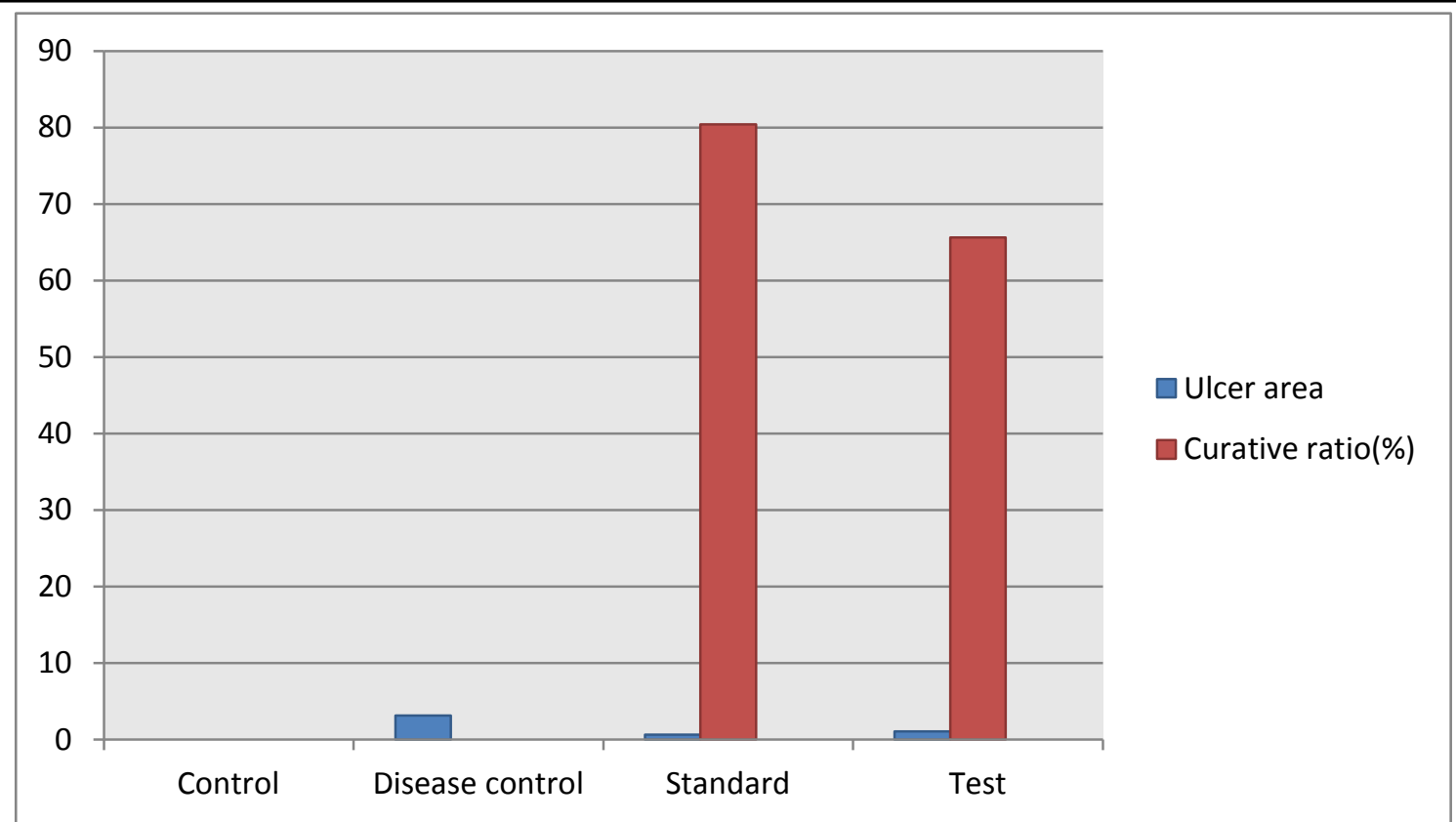

Graph 1: Graphical representation of effect on ulcer area and \% inhibition by GSTE.

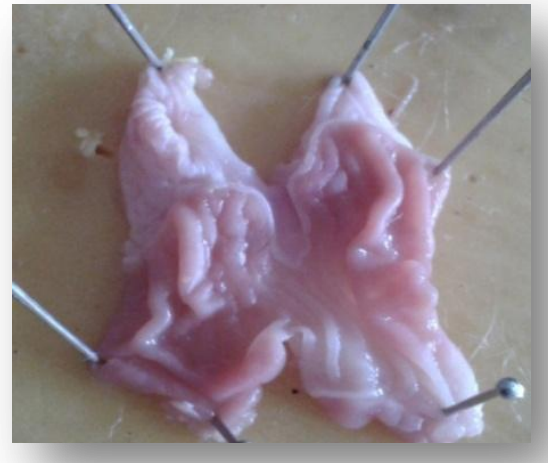

Normal Group

(Saline)

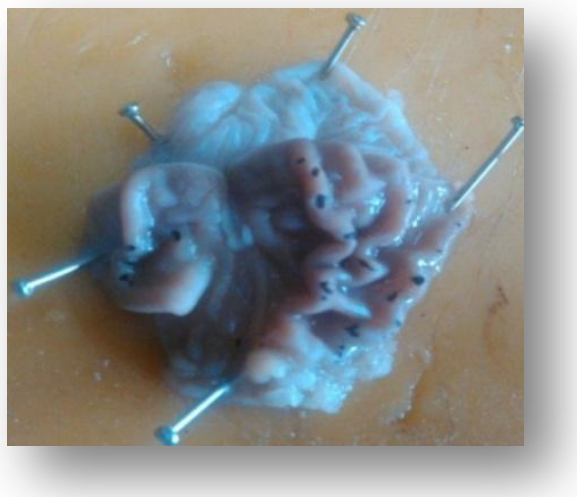

Disease control group

(Indomethacin $25 \mathrm{mg} / \mathrm{kg}$ )

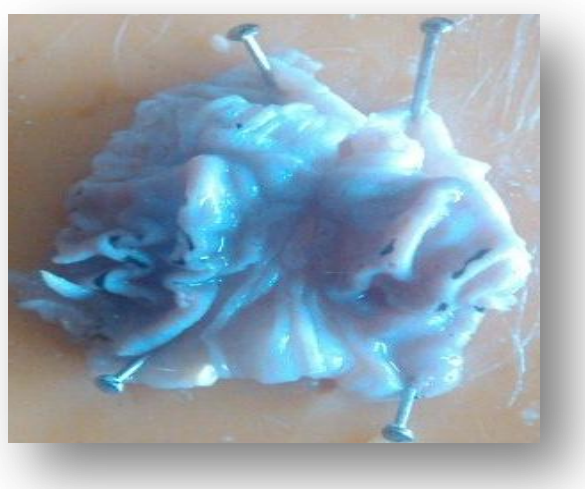

Standard group

(Ranitidine $50 \mathrm{mg} / \mathrm{kg}$ )
Test group

(GSTE $110 \mathrm{mg} / \mathrm{kg}$ )

Figure 1: Gross appearance of gastric mucosa in rats 


\subsection{Comparison of enzyme activities in rat} stomach tissues

Antioxidant defence mechanism play a vital role in ulceration process. Antioxidant enzymes such as LPO, SOD, GSH, and GSH Px were evaluated in stomach tissues. Results are showed in table and fig. In Indomethacin treated rats, there was decrease in levels of SOD, GSH, and GSH Px as compared to control group. There was significant increase in levels of SOD, GSH, GSH Px in rats pre-treated with Ranitidine and test drug (Gloriosa superba). On other hand, there was increase in level of LPO in Indomethacin treated rats which was significantly reduced by administration of Ranitidine and test drug $(\mathrm{p}<0.005)$.

Table-2: Effect of GSTE on biochemical parameters (SOD, LPO, GSH, GSHPx).

\begin{tabular}{|l|l|l|l|l|l|}
\hline Treatment & $\begin{array}{l}\text { Dose } \\
(\mathrm{mg} / \mathrm{kg})\end{array}$ & $\begin{array}{l}\text { SOD } \\
(\mathrm{u} / \mathrm{g} \text { tissue })\end{array}$ & $\begin{array}{l}\mathrm{LPO} \\
(\mathrm{nm} / \mathrm{mg} \\
\text { tissue })\end{array}$ & $\begin{array}{l}\text { GSH } \\
\text { (um/mg } \\
\text { tissue) }\end{array}$ & $\begin{array}{l}\text { GSHPx } \\
(\mathrm{nm} / \mathrm{min} / \mathrm{ml} / \mathrm{mg} \\
\text { tissue) }\end{array}$ \\
\hline $\begin{array}{l}\text { Control } \\
\text { group }\end{array}$ & Saline & $\begin{array}{l}2.702 \pm \\
0.0179 * * *\end{array}$ & $\begin{array}{l}12.84 \\
0.1028 * * *\end{array}$ & $\begin{array}{l}5.133 \pm \\
0.0538^{* * *}\end{array}$ & $\begin{array}{l}10.59 \pm \\
0.0714 * * *\end{array}$ \\
\hline $\begin{array}{l}\text { Disease } \\
\text { control group }\end{array}$ & 25 & $1.706 \pm$ & $26.01 \pm$ & $3.160 \pm$ & $4.952 \pm$ \\
\hline $\begin{array}{l}\text { Standard } \\
\text { group }\end{array}$ & 50 & 0.0090 & 0.2947 & 0.0804 & 0.1990 \\
\hline Test group & 110 & $\begin{array}{l}2.465 \pm \\
0.0109 * * *\end{array}$ & $\begin{array}{l}15.36 \pm \\
0.0590^{* * *}\end{array}$ & $\begin{array}{l}4.838 \pm \\
0.0546 * * *\end{array}$ & $\begin{array}{l}8.871 \pm \\
0.1044 * * *\end{array}$ \\
\hline
\end{tabular}

Animal number $(\mathrm{N})=6$

The measurements were calculated from three replicates.

Each data suggest Mean \pm SEM. One way ANOVA Dunnett's test is applied for statistical analysis.

$* * *$ Significance at $\mathrm{p}<0.05$ when test and standard group were compared with Indomethacin treated group.

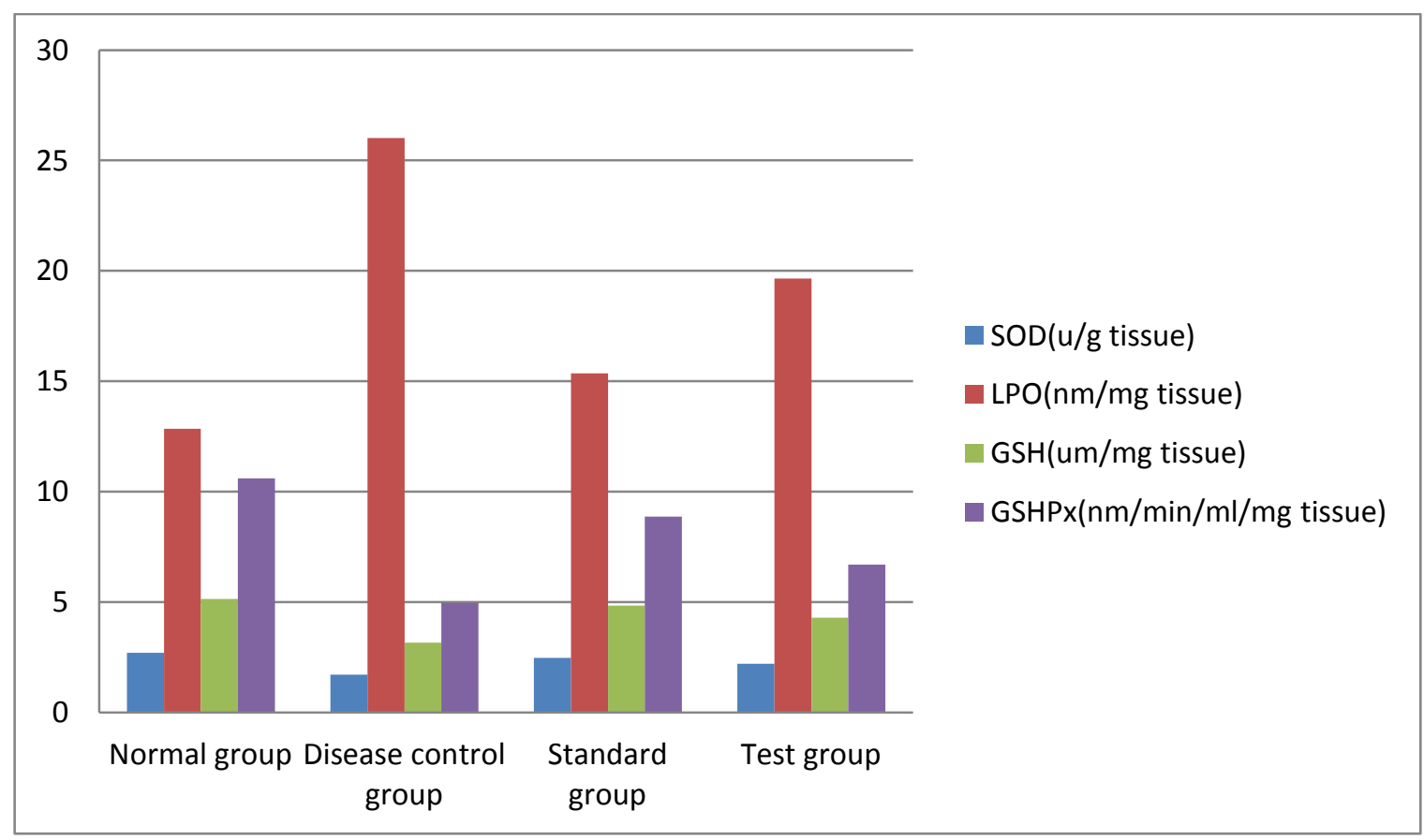

Graph 2: Graphical representation of effect on biochemical parameters (SOD, LPO, GSH, GSHPx) by GSTE 


\subsection{Histopathological studies}

The stomach sections of animals treated with Indomethacin revealed that There was sever destruction of surface epithgelium/ulcer and necrosis in superficial mucosa $(+)$ along with moderate submucosal edema $(++)$ and infiltration of leucocytes $(++)$. Animals pretreated with ranitidine showed that there was mild submucosal edema. Microscopic examination of sections of rats tresated with test $\operatorname{drug}(\mathrm{G}$.superba extract 110 $\mathrm{mg} / \mathrm{kg}$ ) revealed that There was mild destruction of surface epithgelium/ulcer and necrosis in superficial mucosa(+) along with mild submucosal edema and infiltration of leucocytes(+).

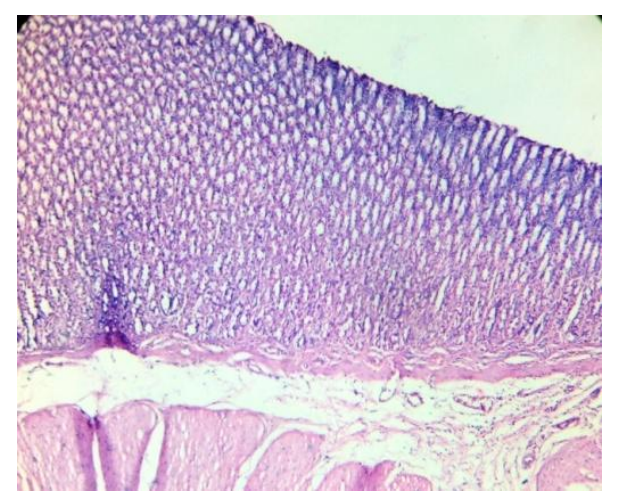

Normal group

(Saline)

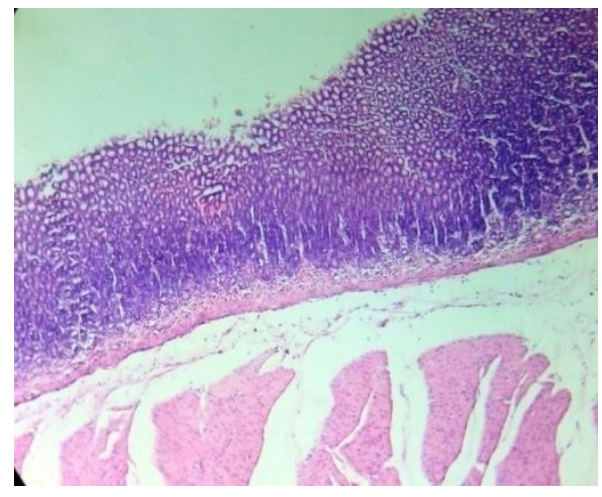

Test group

(110mg/kg)

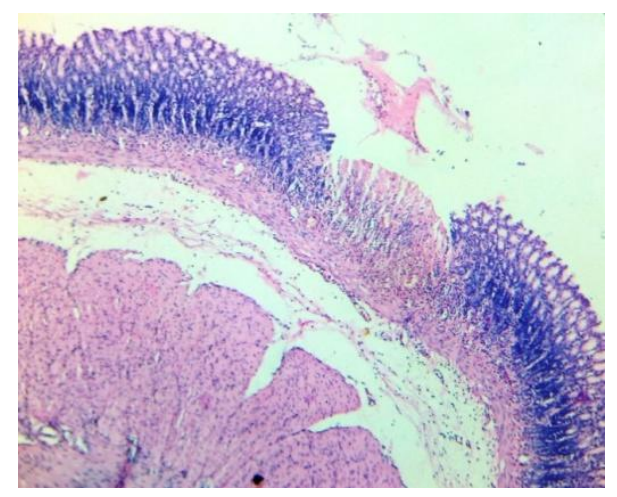

Disease control group

(Indomethacin $25 \mathrm{mg} / \mathrm{kg}$

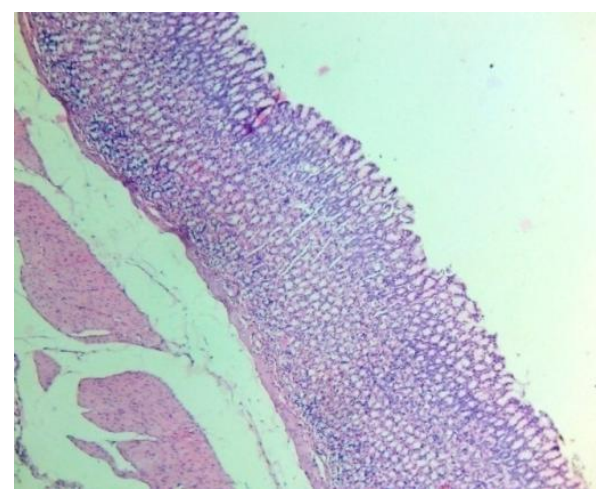

Standard group

(Ranitidine 50mg/kg)

Figure 2: Histological study of Indomethacin induced gastric mucosal damage in rats.

\section{DISCUSSION}

The present study was undertaken with the objective of exploring Gastroprotective activity of extract from Gloriosa superba (glory lily). Glory lily tuber extract showed presence of Flavonoids, tannins, glycosides, steroids, Alkaloids, carbohydrates and mucilage's. TLC and HPTLC were done to confirm the presence of tannins (Gallic acid).

No toxic reactions were observed from acute toxicity study, thereby suggesting the non-toxic nature of Gloriosa superba methanolic extract at a dose of $110 \mathrm{mg} / \mathrm{kg}$ (OECD 423) till the end of experimental period.

Medicinal plants have been successfully used for gastroprotection against NSAIDs. Indomethacin, a NSAID widely used to treat arthritis, causes gastric lesions through the inhibition of the cyclooxygenase (COX) enzyme, resulting in decreased prostaglandin biosynthesis. The resulting mucosal injury is attributed to decreased bicarbonate and mucus secretion and mucosal blood flow, enhanced acid back-diffusion, and inhibition of mucosal injury repair. It has been also shown that 
ROS possess an important role in the pathogenesis of mucosal damages caused by Indomethacin. Superoxides produced by peroxidases in the tissues might damage the membranes and stomach tissues by increasing the lipid peroxidation. Similarly, our results showed that there was a significant increase in the LPO level in rat stomach tissues-administrated with indomethacin. However, significant decreases in the LPO level were observed by the administration of Gloriosa superba extract and ranitidine $(50 \mathrm{mg} / \mathrm{kg}$ body weight). On the other hand, organisms have enzymatic and non-enzymatic defenses, including SOD, GSH, GPx and GR against to the lipid peroxidation in tissues, caused by ROS. In the present study, the levels of SOD, GPx and GSH in rat stomach tissues were significantly reduced by administration of Indomethacin. Contrarily, the administration of Gloriosa superba extract and ranitidine $(50 \mathrm{mg} / \mathrm{kg})$ resulted in a significant increase in the SOD, GPx and GSH levels. This increase may be due to an increase in the mucosal $\mathrm{H} 2 \mathrm{O} 2$ and $\mathrm{OH}-$ level, occurred by inhibition of peroxidases. The activities of these enzymes were lowered by the administration of Gloriosa superba extract, which can be attributed to the decrease in the tissue $\mathrm{H} 2 \mathrm{O} 2$ and $\mathrm{OH} \bullet$ levels.

\section{CONCLUSION}

It can be concluded that Indomethacin induces gastric ulcers by various mechanisms. But with the pre-treatment of Gloriosa superba tuber extract shows that gastric ulcers were significantly reduced and reducing effect against oxidative damage. Therefore GSTE can be used as a gastroprotective agent. Further experimental and clinical studies are needed for confirmation.

\section{ACKNOWLEDGEMENT}

With the guidance and support I received, I would like to thank from the bottom of my heart, my guide Mrs.rachana D. Sarawade. I would like to thank my principal, Dr.Parag Gide and my college Dr.L.h.Hiranandani College of pharmacy for providing suitable environment for research work and facilities. I would like to thank my teaching staff and non teaching staff. I am glad to thank my almighty god, parents, colleagues and everybody who are indirectly connected to research work.

\section{REFRENCES}

1. Heyam Mohamed Ali Sidahmed, Ainnul Hamidah Syahadah Azizan, Syam Mohan; Gastroprotective effect of desmosdumotin $\mathrm{C}$ isololation from Mitrella Kentii against ethanol-induced gastric mucosal hemorrhage in rats: Possible involvement of glutathione, heat- shock protein, sulfhydryl compounds, nitric oxide, anti-helicobacter pylori activity; BMC complementary and alternative medicine; 2013, 13:183.

2. KP.Latha, H.Kirana and HN.Girish; AntiImplantation activity of the hydro alcoholic tuber extract of Gloriosa superba Linn in female Albino rats; IJAPBC-vol.2 (3); jul-sep, 2013.

3. Saradha devi Muthukrishnan, Annapooorani Subramaniyam; International journal of pharmaceutical research development (IJPRD); 2013; vol 5(06) Aug-2013(102-108).

4. CK Kokate, Practical Pharmacognosy; $4^{\text {th }}$ edition; Vallabh Prakashan; New Delhi.

5. GE Trease, WC Evans; Pharmacognosy, $15^{\text {th }}$ edition; WB Saunders Publishers.

6. OECD Guideline for testing of chemicals; 423 Adopted: $17^{\text {th }}$ Dec 2001.

7. Fehmi Odabasoglu, Ahmet Cakir b, Halis Suleymanc, Ali Aslan d, Yasin Bayir a, Mesut Halici a, Cavit Kazaz; Gastroprotective and Antioxidant effect of Usnic acid on Indomethacin- induced gastric ulcers in rats; Journal of Ethnopharmacology 103(2006) 59-65.

8. Sati Al-dalain, Mona 12 S, El-Kutry and 3 Hoda S. Ibrahim; Inhibitory Effect of Aqueous extracts of Barley and Fenugreek on Ulcer induction in rats; World applied Sciences Journal 5(3): 332-339, 2008.

9. Ahmed S. AlRashidi, Suzy M.Salama, Salim S. Alkiyumi, Mahmood A Abdulla, A. Hamid A. Hadi, Siddig I.Abdelwahab, 
Manal M Taha, Jamal Hussiani, and Nur Asykin; Mechanism of gastroprotective effect of ethanolic leaf extract of Jasminium sambac against $\mathrm{Hcl} /$ Ethanol induced gastric mucosal imjury in rats; Hindawi Publishing Corporation, Volume 2012, Article ID 786426.

10. K.T. Mani, Senthnil Kumar 1, Zothan Puia1, Samir K. Samanta1, Rajiv Barik 1, Arnab Dutta 1, Bapi Gorain 1, Dilip K. Roy1, Dipan Adhikari 1, Sanmoy Karmakar1, Tuhinadri Sen; The gastroprotective role of Acanthus ilicifolius- A study to unravel the underlying mechanism of Anti-ulcer Activity; sci Pharm. 2012; 80: 701-717. 